\title{
Chancery English Empowering Women Against Violence
}

\author{
Brooke Garceau ${ }^{1}$ a \\ ${ }^{1}$ English, Dixie State University \\ Keywords: mental health, feminism, narrative, scribes, history of english, middle ages, justice, sexual violence, english language, chancery \\ https://doi.org/10.36898/001c.12798
}

Curiosity: Interdisciplinary Journal of Research and Innovation

Vol. 1, 2020

\begin{abstract}
The benefits of Chancery English extend beyond linguistics and into social justice and healing for victims of sexual violence. Chancery English resulted in clearer, more concise prose which allowed the stories of victims to be recorded effectively. Scribes recorded these stories in court petitions seeking punishment for rapists and murderers. Existing research shows that the use of narrative helps victims to heal from sexual violence. The main texts for the current analysis are Chancerystyle court petitions of three women all named Isabelle. The analysis demonstrates how these petitions and the women they concern (or their surviving loved ones) benefited from Chancery prose and were, therefore, able to bring about a greater degree of healing and justice in the human fight against sexual violence.
\end{abstract}

While Chancery English resulted in various benefits to the English language as a whole, this paper will primarily discuss its impact on prose. Seth Lerer, author of Inventing English: A Portable History of the Language, gives the following explanation of Chancery: "It was a kind of 'Secretariat of State' which not only produced texts" in or for official church and court matters in England, "but trained scribes to write them" in the thirteen and fourteen hundreds (2015, p. 115) Lerer goes on to say, "The prose of [Chancery] documents needed to be understood by readers coming from different regions of the country or with different levels of literacy. And, as most of the documents in Chancery English were really kinds of letters-addresses, petitions, legal requests - that prose needed to be unambiguously direct" (2015, pp. 115-116). This directness of prose which developed out of the Chancery style of writing enabled authors to communicate their ideas more clearly and effectively than ever before. However, the benefits of Chancery English extend beyond the sphere of linguistics and into the sphere of social justice as seen in the ability of women to testify of and seek justice for acts of rape and other violence which they endured as recorded in Chancery-style legal petitions. In order to demonstrate that the prose of Chancery English empowered women in this manner, this paper will establish the benefit of articulating stories of trauma and refer to several Chancery-style petitions written on behalf of women who were raped, otherwise sexually assaulted,

\footnotetext{
a Brooke Garceau is a Senior at Dixie State University pursuing a Bachelor of Art in English with an emphasis in Professional and Technical Writing. Her research interests include feminism, mental health, public relations, and disability advocacy. She has previously been published in the Dixie Sun News, the St. George News, and the DSU Academic Report of 2019.
} 
and murdered. Furthermore, the empowerment which Chancery English gave to these women contributed to an ever-growing foundation of support for women who still face and fight against violence.

Background: Establishing Benefits of Narrative in Healing from Trauma

Since Chancery English resulted in more direct, effective prose, women of the time were able to tell their stories (through the scribes who wrote for them) in an attempt to obtain appropriate sentencing for their abusers and healing, when possible, for themselves. The ability to tell stories of trauma before Chancery prose would have been limited by the constraints of the language, and that limited ability would have, in turn, resulted in a lack of healing for victims of violence. The Survivors' Trust, a UK-based group of 128 non-profit organizations which have united to support victims and survivors of sexual assault and to fight against sexual assault through information and advocacy, states the following: "It is not uncommon for survivors to feel alone and isolated. For many, hearing and sharing stories can play a vital role in their recovery from trauma." While the stories of trauma found in Chancery petitions differ greatly in style and voice from survivor stories of today, they demonstrate a cooperation of victims, their loved ones, and the legal system to seek healing for victims and society-a cooperation evident in either form of narrative. In an article on the power of narratives of sexual violence in the US military, Valerie N. Wieskamp presents an overview of peer-reviewed research which documents the benefits of narrative in healing from sexual trauma:

[S]cholarship has documented the healing and transformative potential of narrative's capacity to create meaning by establishing causality.... Narrative has a 'consoling function,' as it finds 'a shape, a form, in the turmoil of human experience' (Eco, 1994, p. 87). This sense-making process of putting a form to one's trauma has emotional benefits (French, 2003; Kellas, Horstman, Willer, \& Carr, 2015; Rossetto, 2014). There are also physical health benefits to narrating traumatic experiences (Pennebaker, 1997; Pennebaker \& Chung, 2011). Personal storytelling in the public sphere may serve as 'part of a social process of coping' (Langellier, 1989, p. 164). Ellis and Patti (2014) observe that sharing and hearing personal stories of vulnerability help us 'work through our own struggles with more grace, dignity, and humanity' ( $\mathrm{p}$. 94). (2019, pp. 135-136).

Beyond establishing basic benefits of narrative in healing from trauma, Wieskamp also discusses what kinds of narrative are beneficial in the healing process for victims of sexual violence. She writes, "Transformative stories must both highlight the systemic nature of the problem while also positioning survivors as experts so as to render the act of publicly sharing trauma empowering" (2019, p. 134). As the petitions referenced below do not record first-person accounts of trauma, they do not fully meet the requirement of positioning survivors as experts. Two of the petitions are written in behalf of 
women who were murdered by their attackers (Fisher et al., 1993), rendering them incapable of seeking justice for themselves. The petition written in behalf of Isabell of Lancashire lists her as the "Besecher" (Fisher et al., 1993), implying that she took an active role in seeking justice and healing for herself. Moreover, the very existence of these petitions does demonstrate a trust in the character of the women concerned and an acknowledgment of the horrors they endured as real.

Chancery Petitions Documenting Justice Being Sought By or in Behalf of Women in Cases of Sexual Violence

The petitions containing stories of trauma discussed in this work are found in An Anthology of Chancery English and are entitled "Petition concerning the murder of Isabell by her husband John Carpenter of Sussex," "Petition concerning rape of Isabell, wife of John Boteler of Lancashire," and "Petition concerning murder of Isabell, wife of Roger Bakeler, by John Bolton.” Because all three women in these petitions share the first name Isabell, they will be referred to hereafter as Isabell of Sussex (from the first petition), Isabell of Lancashire (from the second), and Isabell of Surrey (from the third). Following are summaries of the stories of these women which include excerpts from the petitions named above.

\section{Isabell of Sussex}

Isabell of Sussex "was of the Age of xvje yere" and had been married to her husband, John Carpenter, for fifteen days when he told her to "arraye hir in hir best arraie" because they were going on a trip together. He took her to the woods of a nearby town and killed her with a knife. The petition gruesomely details that brain matter was found on her body and that her husband "streped hir naked and toke his knyff and slitte hir bely fro the breste doun \& (toke hir bowels oute of hir body and) loked if she were with Childe" The petition asks that Isabell's husband "be draw. And hanged as a Traytour (Fisher et al., 1993).

\section{Isabell of Lancashire}

Isabell of Lancashire was attacked in her own home by William Pulle and a "grete number of other mysdoers." Pulle "felonousely and moste horribely rauysshed" Isabell in her own home and kidnapped her, taking her away to Wales while she wore only "hir kirtyll and hir smoke." He then kept her "in other secrete places" until she was rescued and safeguarded pending his capture. Isabell is, as stated above, listed as "beseecher" in this petition, showing her involvement in pursuing punishment for Pulle and healing for herself. Her petition requests that Pulle be charged with high treason and killed if he does not appear in court to account for his crimes on an appointed day (Fisher et al., 1993).

\section{Isabell of Surrey}

Isabell of Surrey was attacked by John Bolton. He "wold haue rauesshed Isabell" but "sche wold not assent vn to him he vilanisly toke of here all the Atire of her hede And al so her clothes of her body otake her smoke. And yet sche wolde neuer assent vn to his vnlefull desir." The petition goes onto say 
that "at the last be cause he coulde noghte haue his desir of her. He ther at the same tyme felonesly sloeth and murdred her and kutte her throte twyes. And twyes stikked her thurgh her pappes and sides with a dagger where vppon sche died." Isabell's murderer had, it seems, applied for a pardon from all his crimes and received it, the king not knowing of his attack on Isabell. The petition written in Isabell's behalf requested that her murderer be held accountable for his crimes and that he be punished for high treason (Fisher et al., 1993).

Analysis: Detailed Stories of Trauma Written in Chancery Prose

The stories of each of these women written in Chancery-style petitions record in great detail the crimes committed against them. The direct prose that resulted from Chancery English made this level of communication possible, which also opened an avenue for Isabell of Lancashire and the surviving loved ones of Isabell of Sussex and Isabell of Surrey to pursue justice. As only a small portrait of the experiences of Isabell of Lancashire can be formed from her petition, one can only hope that the telling of her story brought her a measure of healing as well.

The details supplied in the petitions described above combine to tell the stories of trauma of these three Isabells. In "Writing Wrongs: The Drafting of Supplications to the Crown in Later Fourteenth-Century England," Gwilym Dodd lists some of the rules of petitioning the king in court which bled into petitionary writing. Dodd gives the following examples: "the accused needed to be fully and correctly identified; the allegations of wrongdoing needed to be time-specific and accurately located; and the crimes described in appropriate detail” (2011, p. 221). The requirement of such details coupled with the direct prose of Chancery English preserved the accounts of Trauma which these women faced. Without the requirement of such details, the accounts might have been nothing more than a brief statement of the crime, and without the direct Chancery prose, the accounts might have been unreadable.

Readers of the petitions find details in locations, weapons, and clothing. In Isabell of Sussex's petition, we learn that she was murdered in the woods near "the Toun of Stoghton." In Isabell of Lancashire's petition, we learn that she was raped in her own home in Beausey and then kidnapped and taken to Wales. These details of location document the settings in the stories of trauma for these women. In each petition, we learn of the weapons used to assault these women: a knife against Isabell of Sussex, a dagger against Isabell of Surrey, and "armes in riotouse manere" against Isabell of Lancashire. These details provide evidence that these women were attacked violently and with the intent to harm, if not to kill. We also learn of the clothing each woman wore, often described in a list of clothing which their attackers removed from their bodies. Isabell of Sussex was wearing "hir best arraie," and Isabell of Surrey wore "a gowne. A kirtell. A hode. Two kirchieffes and two keyes vppon her." These details serve to remind the reader of the humanity of these women as they bring relatable, human portraits of these women to our minds. All such details fill the lines of Chancery prose with that quality of humanity which is so necessary in the stories of trauma which promote healing (Fisher et al., 1993). 
Discussion: Prose of Chancery Petitions Extending to Protect and Empower Future Women

The stories of Isabell of Sussex, Lancashire, and Surrey added crucial strength to the movement of believing, helping, and empowering victims of sexual trauma and physical abuse. In Isabell of Surrey's petition, we read the plea, "And yf any man desire here after to Rauisshe Any woman) and for cause that sche wolle noghte assente (vnto hym sle and) murder her that any charter to be made to any suche person for any suche murder (be) voide and noghte auaillable in lawe for the loue of ihesu and yn way of charite (Fisher et al., 1993).” Although some might read this plea as insufficient, as lacking protection from rape, the plea does ask for protection from murder committed because a woman refused to let a man rape her. In providing a penalty for men who would do the same thing to future women that Isabell's murderer did to her, the petition seeks to discourage or prevent similar trauma from happening. In "Recovery from Trauma: A Look Into the Process of Healing from Sexual Assault," Julia Skinner describes her own trauma and healing process and gives perspective on how victims of sexual trauma can make meaning from their trauma. She writes, "My account also ties in to Erickson's notion of generativity - the idea that we can create meaning for ourselves by sharing our experiences and leaving something to future generations (Erikson \& Coles, 2000 , p. 204). It allows me a framework in which to be proactive and use my experience as a means to aid and educate others" (2009, p. 179). While Isabell of Surrey herself would not have been able to find this kind of meaning by helping others because of her death, perhaps those who sought justice on her behalf found something similar. Perhaps in helping to protect other women from suffering Isabell's fate they found a pathway for healing from their own grief at her pain and loss.

Conclusion:

Whatever the benefits of the stories of these women being recorded might have been for their contemporaries, victims of sexual and other forms of violence benefit from them now. The scribes who wrote the petitions about Isabell of Sussex, Isabell of Lancashire, and Isabell of Surrey contributed strength to the foundation of justice and healing of all victims of such trauma. These stories of trauma, recorded for the purpose of legal proceedings, one might say, are some of the first narratives of sexual trauma in the English language and have opened the way for current survivors of trauma to share their own experiences. Movements like \#MeToo might find their roots in the stories of justice being pursued in behalf of these women named Isabell, and, at the very least, the women who speak out in such movements can find strength and healing in knowing that they have not suffered, survived, and sought for justice alone, but together with women through the ages. As we continue this fight for justice, perhaps we can leave a similar legacy for the women who follow us, and perhaps, with each generation, we can advance our position and eventually gain the ultimate victory. 
This is an open-access article distributed under the terms of the Creative Commons Attribution 4.0 International License (CCBY-SA-4.0). View this license's legal deed at https://creativecommons.org/ licenses/by-sa/4.0 and legal code at https://creativecommons.org/licenses/by-sa/4.0/legalcode for more information. 


\section{References}

Dodd. (2011). Writing wrongs: The drafting of supplications to the crown in later fourteenth-century England. Medium Avum, 80(2), 217. https://doi.org/10.2307/43632872

Fisher, J., Richardson, M., Fisher, J., \& University of Michigan. (1993). An anthology of Chancery English. University of Michigan Humanities Text Initiative. https://quod.lib.umich.edu/cgi/t/text/ text-idx? $\mathrm{c}=\mathrm{cme} ; \mathrm{idno}=$ ChancEng

Lerer, S. (2015). Inventing English: A portable history of the language, revised and expanded edition. Columbia University Press. https://doi.org/10.7312/lere17447

The Survivors Trust. (2020). Survivor stories. http://www.thesurvivorstrust.org

Wieskamp, V. N. (2019). "I'm Going Out There and I'm Telling This Story": Victimhood and Empowerment in Narratives of Military Sexual Violence. Western Journal of Communication, 83(2), 133-150. https://doi.org/10.1080/10570314.2018.1502891 